Wawasan

Jurnal Kediklatan Balai Diklat Keagamaan Jakarta

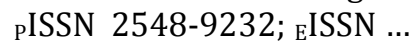

Volume 1 Nomor 1 Tahun 2020

\title{
EFEKTIVITAS LEARNING MANAGEMENT PADA DIKLAT TEKNIS SUBSTANTIF PKG DAN PKB BAGI GURU MADRASAH DI LINGKUNGAN BALAI DIKLAT KEAGAMAAN BANDUNG
}

\author{
Mohammad Fauzan \\ Balai Diklat Keagamaan Bandung, Indonesia \\ E-mail:fmofa172@gmail.com
}

\begin{abstract}
This research aims to explain the effectiveness of learning management and obstacle of PKG and PKB training for Madrasah 'Aliyah teachers at the Bandung Religious Education and Training Center in 2018. The research is descriptive using observation and interview technique of data collection. Data was analyzed by qualitative data analysis techniques through three stages namely data reduction, display, and verification. The results of this study revealed that the education and training process is effective with the final average score of all indicators of 88.53 (very good). The obstacles found during the training management process lie in the management of the training material and the management of the leaning organization. The research recommends touse a variety of learning methods through grouping training participants and collaboration in working on the worksheets.
\end{abstract}

Keywords: Effectiveness; Learning Management; Training

\begin{abstract}
Abstrak
Penelitian ini dilakukan dengan tujuan untuk mengetahui efektivitas pengelolaan pembelajaran pada diklat PKG dan PKB bagi guru Madrasah 'Aliyah di Balai Diklat Keagamaan Bandung pada Tahun 2018 dan untuk mengetahui kendala serta hambatan yang ditemui selama dilaksanakan proses kediklatan. Jenis penelitian deskriptif dengan pendekatan kualitatif pada penelitian ini untuk mengungkap fakta dan fenomena dilapangan apa adanya. Teknik pengumpulan data pada penelitian ini adalah menggunakan lembar observasi dan wawancara tidak terstruktur. Peneliti menggunakan teknik analisis data kualitatif melalui tiga tahapan analisis, yaitu reduksi data, display, dan verifikasi. Hasil penelitian ini terungkap bahwa proses pembelajaran diklat telah berjalan efektif dengan skor akhir rerata dari semua indikator sebesar 88,53 dengan predikat sangat baik atau terpenuhi dengan sangat baik. Hambatan-hambatan yang ditemukan selama proses pengelolaan diklat terletak pada pengelolaan materi diklat dan pengelolaan organisasi pembelajaran. Solusi nya adalah dengan menggunakan metode pembelajaran yang bervariasi melalui pengelompokkan peserta diklat dan kolaborasi dalam mengerjakan lembar kerja yang telah disediakan widyaiswara.
\end{abstract}

Kata Kunci: Efektifitas; Pelatihan; Pengelolaan Pembeajaran 


\section{PENDAHULUAN}

Pada Peraturan Kepala Lembaga Administrasi Negara Nomor 5 Tahun 2008 tentang Standar Kompetensi Widyaiswara Bab IV Pasal 5 menyebutkan bahwa standar kompetensi widyaiswara terdiri atas: a) Kompetensi pengelolaan pembelajaran, b) Kompetensi kepribadian, c) Kompetensi sosial, dan d) Kompetensi substantif. Pengelolaan pembelajaran merupakan kemampuan widyaiswara dalam mengelola seluruh rangkaian proses kegiatan yang terjadi sejak merencanakan, menyusun bahan ajar, melaksanakan interaksi dengan peserta diklat dalam kegiatan pembelajaran agar tercapai tujuan pembelajaran sampai mengevaluasi pembelajaran.

Kemudian pada Pasal 6 ayat 1 dan 2 menjelaskan tentang kompetensi pengelolaan pembelajaran, adalah kemampuan yang harus dimiliki Widyaiswara dalam merencanakan, menyusun, melaksanakan dan mengevaluasi pembelajaran. Kompetensi pengelolaan pembelajaran tersebut meliputi kemampuan: a) membuat Garisgaris Besar Program Pembelajaran (GBPP)/Rancang Bangun Pembelajaran (RBP) dan Satuan Acara Pembelajaran (SAP)/Rencana Pembelajaran (RP), b) menyusun bahan ajar, c) menerapkan pembelajaran orang dewasa, d) melakukan komunikasi yang efektif dengan peserta, e) memotivasi semangat belajar peserta, dan f) mengevaluasi pembelajaran.

Kompetensi pengelolaan pembelajaran widyaiswara dalam konteks kediklatan memiliki fungsi strategis dan berpengaruh penting dalam mencapai tujuan pembelajaran (Hidayat, \& Sa'ud, 2015; Susetyowati, 2019). Kegiatan widyaiswara dalam proses merencanakan dan menyusun tergambar pada kegiatan membuat Garis-garis Besar Program Pembelajaran (GBPP)/Rancang Bangun Pembelajaran (RBP dan Satuan Acara Pembelajaran (SAP)/Rencana Pembelajaran (RP) dengan kegiatan menyusun bahan ajar serta kegiatan mengevaluasi pembelajaran tidak akan menjadi bahasan utama dalam penulisan dan penelitian ini. Peneliti berfokus pada bagaimana widyaiswara mengembangkan kompetensi dalam hal melaksanakan kegiatan diklat sebagaimana dinyatakan dalam PerKa LAN No. 5 Tahun 2008 dengan 3 sub kompetensi berikut, yaitu; menerapkan pembelajaran orang dewasa, melakukan komunikasi yang efektif dengan peserta, dan memotivasi semangat belajar peserta.

Beberapa penelitian yang telah dilakukan sebelumnya, menjelaskan bahwa kompetensi pengelolaan pembelajaran, kecerdasan interpersonal dan komitmen guru berpengaruh positif langsung terhadap kepuasan kerja (Sumantri, 2013; Bahrunm 2018). Hal ini memberi implikasi bahwa kepuasan kerja guru dapat ditingkatkan melalui pengembangan kompetensi pengelolaan pembelajaran, peningkatan kecerdasan interpersonal dan peningkatan komitmen guru (Sumantri, 33-34: 2012).

Berkaitan dengan penelitian yang dilakukan peneliti tentang efektivitas pengelolaan pembelajaran pada diklat, maka yang perlu digarisbawahi dalam artikel ini adalah bagaimana pengelolaan pembelajaran pada kegiatan pendidikan dan pelatihan tersebut berdampak terhadap ketercapaian tujuan yang sudah direncanakan.

Artikel penelitian ini mencoba mengupas efektivitas pengelolaan pembelajaran yang dilakukan oleh widyaiswara selama melaksanakan proses kegiatan pada Diklat Teknis Substantif Peningkatan Kompetensi PKG dan PKB. Rumusan masalah penelitian ini sebagai berikut: Apakah pelaksanaan pengelolaan pembelajaran telah berjalan dengan efektif? Bagaimana efektivitas pelaksanaan pembelajaran? dan Kendala apa saja yang ditemui selama pelaksanaan pengelolaan pembelajaran? 
Tujuan dari penelitian ini adalah: 1) Untuk mengetahui efektif pelaksanaan pengelolaan pembelajaran, 2) Untuk mengetahui efektivitaspelaksanaan pembelajaran, dan 3) Untuk mengetahui kendala atau hambatan dan solusi tercapainya efektivitas pelaksanaan pengelolaan pembelajaran pada Diklat Teknis Substantif Peningkatan Kompetensi PKG dan PKB.

Penelitian ini diharapkan memberi manfaat bagi pengelola dan pemerhati bidang kediklatan mengenai bagaimana meningkatkan efektivitas pelaksanaan pengelolaan pembelajaran untuk mencapai tujuan diklat dan memberi kebermanfaatan bagi peserta diklat mengenai bagaimana proses pengelolaan pembelajaran yang dapat diimplementasikan ditempat kerjanya masing- masing.

\section{METODE}

Penelitian ini mengunakan metode deskriptif yaitu penelitian yang berupaya mendeskripsikan suatu gejala, peristiwa, kejadian yang terjadi pada saat sekarang (Sujana dan Ibrahim, 1989:65). Penelitian ini berusaha mengungkap fakta yang terdapat di lapangan dan memusatkan perhatian kepada pemecahan masalah-masalah aktual sebagaimana adanya pada saat penelitian dilaksanakan.

Penelitian ini dilaksanakan di Balai Diklat Keagamaan Bandung pada 09-14 April 2018. Adapun data primer pada penelitian ini adalah data yang bersumber dari peserta Diklat Teknis Substantif Peningkatan Kompetensi PKG dan PKB bagi guru Madrasah 'Aliyah (MA) berjumlah 30 orang.

Komponen efektivitas pengelolaan pembelajaran terdiri dari 5 aspek yang dirinci kedalam 42 indikator. Untuk menjamin keakuratan dan ketajaman analisis pada data hasil observasi, digunakan juga alat pengumpulan data dengan teknik wawancara.

Data tentang efektivitas pengelolaan pembelajaran dikumpulkan dengan menggunakan angket dengan skala likert skala 5 dengan kualifikasi: 1 tidak terpenuhi, 2 kurang terpenuhi, 3 cukup terpenuhi, 4 terpenuhi dengan baik, dan 5 terpenuhi dengan sangat baik.

Teknik analisis data pada penelitian ini menggunakan pendekatan kualitatif. Teknik analisis data kualitatif yang dilakukan penulis dalam penelitian ilmiah ini mengikuti konsep Miles dan Huberman. Ada 3 tahapan analisis data kualitatif menurut Miles dan Huberman, yaitu reduksi data, display, dan conclusion/verification.

\section{HASIL DAN PEMBAHASAN}

\section{Pengelolan Materi Diklat}

Indikator pengelolaan materi diklat terdiri dari gagasan utama materi diklat, konsep, gagasan, pengetahuan awal, relevansi pokok bahasan materi diklat dan materi diklat yang mampu diaplikasikan dalam pekerjaan.

Informasi yang diperoleh dari lembar observasi mengenai efektivitas pengelolaan pembelajaran pada indikator pengelolaan materi diklat adalah sebagai beriut:

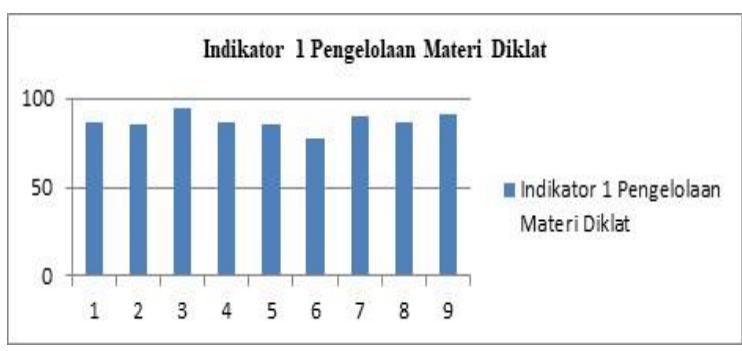

Gambar 1. Diagram Indikator 1 Pengelolaan MateriDiklat 
Wawasan

Jurnal Kediklatan Balai Diklat Keagamaan Jakarta PISSN 2548-9232; ${ }_{\mathrm{E}}$ ISSN ...

Volume 1 Nomor 1 Tahun 2020

Diagram batang di atas menggambarkan keragaman penilaian peseerta mengenai pengelolaan materi diklat. Secara kuantitatif komponen tersebut memperoleh skor rata-rata 87,11 .

\section{Pengelolaaan Organisasi Pembelajaran}

Indikator pengelolaan organisasi pembelajaran terdiri dari 7 sub indikator yang menggambarkan proses dan langkah-langkah pengorganisasian materi diklat, perencanaan kegiatan, apersepsi dan penarikan kesimpulan materi diklat yang merujuk pada gagasan utama.

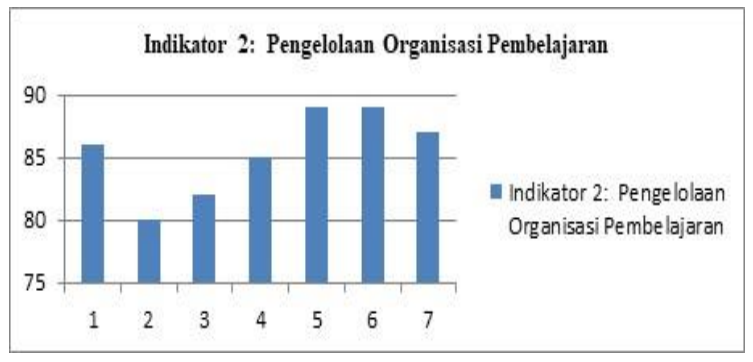

Gambar 2. Diagram Indikator 2

PengelolaanOrganisasi Pembelajaran

Perolehan data sub indikator pengelolaan organisasi pembelajaran seperti pada diagram berikut. Pada indikator 2 mengenai pengelolaan organisasi pembelajaran diperoleh skor rata-rata dari masing-masing sub indikator adalah sebesar 85,52.

\section{Pengelolaan Kelas}

Indikator pengelolaan kelas terdiri dari 8 sub indikator yang mendeskripsikan tentang bagaimana widyaiswara melaksanakan pengelolaan sesuai prinsip andragogi, pelibatan peserta diklat dalam pembelajaran, melakukan komunikasi yang efektif dan penggunaan metode serta teknik yang disesuaikan dengan karakterisitik peserta dan materi diklat. Perolehan dari masing-masing sub indikator pengelolaan kelas adalah sebagai berikut:

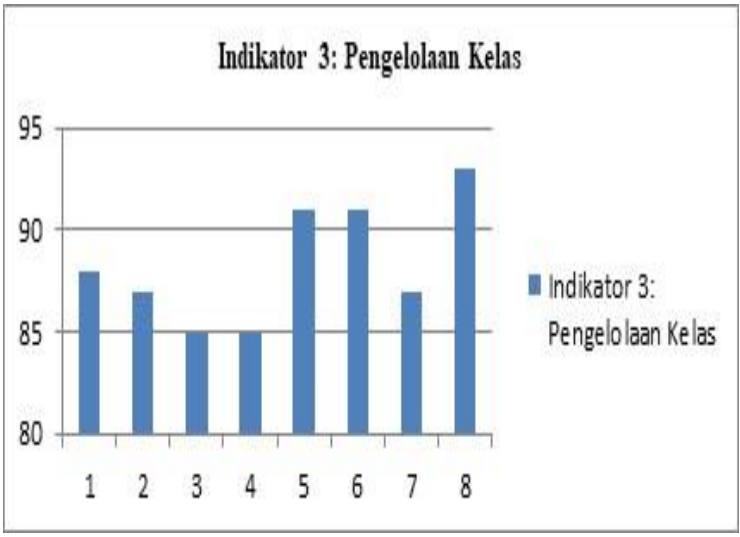

Gambar 3. Diagram Indikator 3 Pengelolaan Kelas

Perolehan skor rata-rata dari masing-masing sub indikator pada indikator pengelolaan kelas adalah sebesar 88,33 .

\section{Pengelolaan Interaksi Widyaiswara dengan Peserta Diklat dan Penggunaan Bahasa}

Indikator ke 4 yaitu interaksi widyaiswara dengan peserta diklat dan penggunaan bahasa selama pelaksanaan proses pembelajaran pada diklat dirinci menjadi 16 sub indikator yang secara umum meliputi keterampilan widyaiswara mengelola hubungan interaksi dengan peserta diklat, melontarkan pertanyaanpertanyaan kepada peserta diklat sebagai stimulant dan memberikan umpan balik serta ketepatan memberikan respon, keterampilan widyaiswara dalam penggunaan bahasa yang mudah difahami peserta, 
aksen berbicara, gesture, kualitas dan volume suara serta rasa percaya diri widyaiswara. Perolehan masingmasing sub indikator tersebut tergambar pada diagram berikut ini:

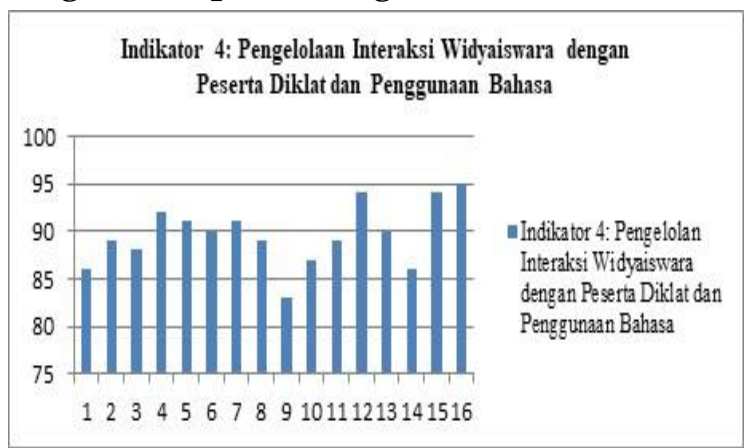

Gambar 4. Diagram Indikator 4

Pengelolaan inetraksi Widyaiswara dengan Peserta Diklat dan Penggunaan

Bahasa

Perolehan skor rata-rata dari masing- masing sub indikator pada indikator pengelolaan interaksi widyaiswara dengan peserta diklat dan penggunaan bahasa adalah sebesar 89,58 .

\section{Indikator Pengelolaan Sarana dan Prasarana Diklat}

Pengelolaan sarana dan prasarana diklat terdiri dari 4 sub indikator yang berkaitan dengan pemanfaatan sarana dan prasarana diklat dalam mendukung pada efektivitas pengelolaan pembelajaran. Perolehan skor masing-masing sub indikator dari indikator pengelolaan sarana dan prasarana diklat adalah sebagai berikut:

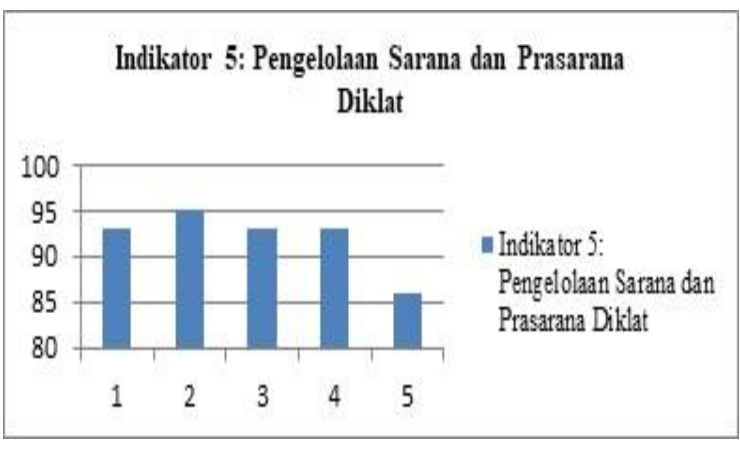

Gambar 5. Diagram Indikator 5

Pengelolaan Sarana dan Prasarana Diklat

Perolehan skor rata-rata keseluruhan sub indikator dari indikator pengelolaan sarana dan prasarana diklat adalah 92,1.

\section{Hambatan Efektivitas Pengelolaan Pembelajaran}

Secara umum dilihat dari skor setiap indikator diklat ini dapat sudah mencapai predikat sangat baik, tidak berarti selama proses pembelajaran pada diklat tidak ada kendala atau hambatan berarti. Peneliti menemukan beberapa hal yang seharusnya menjadi perhatian bagi panitia penyelenggara program diklat dan lembaga Balai Diklat Keagamaan Bandung.

Berdasarkan perolehan skor masing-masing indikator efektivitas pengelolaan pembelajaran, indikator pengelolaan organisasi pembelajaran dan pengelolaan materi diklat memperoleh skor rendah dibandingkan dengan indikator lainnya. Sub indikator dari pengelolaan materi diklat yakni penyampaian informasi dengan metode yang bervariasi dan materi diklat yang membutuhkan keterampilan berfikir sintesis serta analisis memperoleh 
skor paling kecil. Hal ini bisa difahami mengingat materi diklat PKG dan PKB membutuhkan tingkat konsentrasi peserta diklat yang cukup tinggi, analisis terhadap butir-butir PKG dan $\mathrm{PKB}$, menghitung setiap item butir PKG dan PKB serta menuntut peserta diklat terampil dan teliti dalam mengisi lembar kerja (worksheet) yang cukup menguras waktu dan tenaga. Salah satu solusi yang diberikan widyaiswara adalah pengelompokkan peserta diklat sehingga beban selama pengisian lembar kerja terbantu dengan adanya kerjasama masing-masing anggota kelompok.

Kendala berikutnya adalah pada indikator pengelolaan organisasi pembelajaran pada sub indikator pengantar materi disampaikan langkah-langkah kegiatan pembelajaran dan transisi antar tahapan pembelajaran disampaikan dengan jelas dan disertai rangkuman memperoleh skor paling pindah. Alihalih mengenai materi diklat PKG dan PKB yang menuntut konsentrasi peserta diklat yang cukup tinggi, maka widyaiswara dituntut untuk mengembangkan metode dan pendekatan pembelajaran yang tidak rumit serta cara penyampaian materi dengan lugas, tegas dan simpel.Pada catatan peneliti saat sesi wawancara dengan peserta diklat yang dilaksanakan pada rentang waktu istirahat pertama pada pukul 09.4510.00, istirahat ke dua 12.15-13.15 dan istirahat ketiga pada 15.15-15.30, diperoleh informasi bahwa materi diklat PKG dan PKB sebagian besar merupakan materi yang sangat dibutuhkan peserta mengingat peran materi diklat ini menjabarkan tentang betapa pentingnya materi ini diketahui dan dapat dilaksanakan oleh peserta diklat ketika melakukan proses pengajuan kenaikan pangkat dan golongan dengan terlebih dahulu melaksanakan evaluasi diri. Disamping itu materi diklat yang menuntut keterlibatan peserta diklat dalam menghitung setiap butir instrument PKG dan PKB yang cukup menguras tenaga dan fikiran pada akhirnya dapat diperoleh solusi dengan cara melakukan kolaborasi dalam mengerjakan worksheet yang harus diisi secara detil dan transparan oleh peserta diklat melalui metode simulasi.

\section{Pembahasan}

Proses pendidikan dan pelatihan teknis substantif yang dilaksanakan dalam jangka waktu tertentu diharapkan terjadi perubahan yang signifikan terhadap kinerja peserta diklat dan berdampak positif baik secara individual maupun terhadap lembaga pendidikan dimana peserta diklat pengabdi sebagai Aparatur Sipil Negara. Hal ini senada dengan apa yang disampaikan Simamora (1995) dalam Dartha (2010: 157) bahwa tujuan pelaksanaan diklat adalah untuk memperbaiki kinerja pegawai, memudahkan keahlian para pegawai 
sejalan dengan kemajuan teknologi, mengurangi waktu belajar pegawai sepaya menjadi kompeten dibidangnya. Setidaknya terdapat dua manfaat dilksanakannya kegiatan diklat, yaitu dari perspektif organisasi dan perspektif individual. Organisasi atau institusi akan memperoleh pegawai yang terampil, meningkatnya kinerja lembaga dan pegawai yang produktif, juga sebagai individu pegawai, kebutuhan aktualisasi diri terpenuhi dan terbuka kesempatan untuk mendapatkan promosi kenaikan jabatan atau golongan/pangkat.

Proses pembelajaran pada pendidikan dan pelatihan, memberikan kesempatan kepada peserta untuk mengaktualisasikan dirinya melalui proses berbagi pengalaman, pengetahuan, sikap dan keterampilan dengan widyaiswara serta sesama peserta diklat. Proses kediklatan memberi ruang yang sangat memungkinkan peserta diklat saling berinteraksi dengan sesama peserta diklat lainnya. Keterampilan dan pengalaman widyaiswara dalam mengelola sebuah kediklatan berperan sangat strategis bagaimana proses pembelajaran kediklatan terlaksana dengan efektif dan efisien. Berdasarkan pada temuan hasil penelitian dari 5 indikator yang telah ditentukan sesuai dengan lembar observasi yang disebar kepada peserta diklat, maka didapatkan perolehan rata-rata dari masing- masing indikator dengan rincian sebagai berikut:

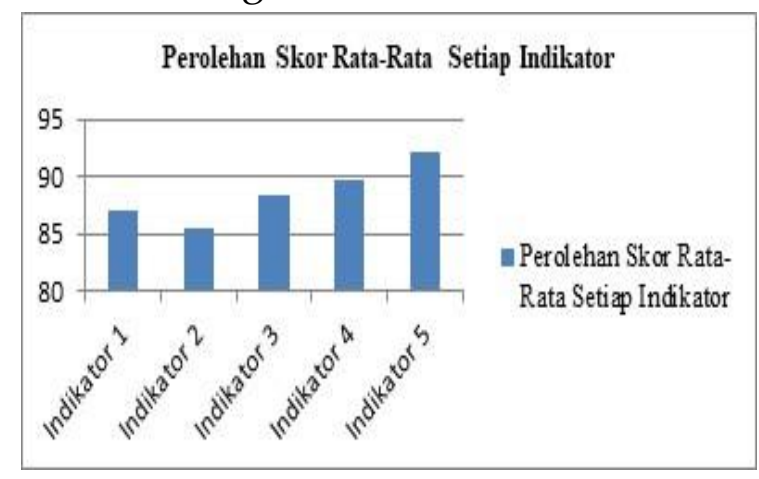

Gambar 6. Diagram Perolehan Skor Rata-rata Setiap Indikator.

Indikator 1, yaitu pengelolaan materi pembelajaran mendapat respon dari peserta dengan skor rata-rata sebesar 87,11. Selanjutnya berturutturut indikator 2 sebesar 85,52, indikator 3 dengan skor 88,33, indikator 4 mendapat 89,58, dan indikator 5 memperoleh skor 92,1. Skor perolehan masing-masing indikator apabila merujuk pada skala dan predikat yang ditentukan dalam metode penelitian di atas dapat dikemukakan pada tabel berikut:

Skor total dari 5 indikator diperoleh nilai rerata sebesar 88,53 dengan predikat sangat baik. Maka dapat dikatakan bahwa proses pembelajaran pada Diklat Teknis Substantif Peningkatan Kompetensi PKG dan PKB Bagi Guru Madrasah 'Aliyah dilingkungan Balai Diklat Keagamaan Bandung Tahun 2018 berjalan efektif. 
Tabel 1 Perolehan Skor Rata-rata dan Predikat Masing-masing Indikator

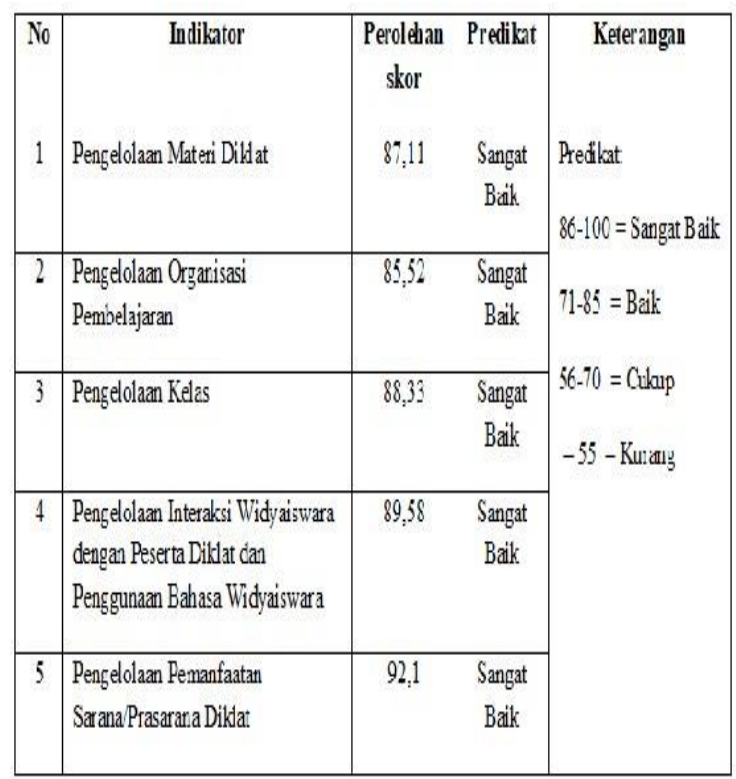

Berdasarkan hasil temuan dan pembahasan pada penelitian ini maka dapat disimpulkan bahwa pengelolaan pembelajaran pada diklat teknis substantif PKG dan PKB bagi guru Madrasah 'Aliyah di Balai Diklat Keagamaan Bandung Tahun 2018 telah berjalan efektif. Hal ini terbukti dengan perolehan skor secara rerata dari keseluruan indikator pengelolaan pembelajaran sebesar 88, 53 dengan predikat terpenuhi dengan sangat baik. Selain itu berdasar pada hasil wawancara dan catatan anekdot peneliti didapat kesimpulan secara umum bahwa diklat PKG dan PKB memberi dampak sangat positif bagi peserta diklat. Efektivitas pengelolaan pembelajaran pada diklat tersebut diperoleh dari persepsi melalui isian lembar instrument observasi dan wawancara serta catatan peneliti yang kemudian diperkuat dengan hasil pengisian lembar penilaian peserta diklat terhadap penyelenggaraan program diklat dalam bentuk lembar observasi yang telah disediakan oleh Balai Diklat Keagamaan Bandung. Adapun kendala yang dihadapi dalam pengelolaan pembelajaran diklat ini adalah pada indikator pengelolaan materi diklat yaitu sub indikator penggunaan metode pembelajaran yang bervariasi serta materi diklat yang menuntut cara berfikir analisis dan sintesis, serta indikator pengelolaan organisasi pembelajaran pada sub indikator langkah-langkah kegiatan pembelajaran dan transisi antar tahapan pembelajaran disampaikan dengan jelas dan disertai rangkuman. Kendala tersebut dapat teratasi dengan metode pembelajaran kolaboratif melalui pengelompokkan peserta diklat sehingga terjalin kerja sama yang baik dimana peserta diklat yang cukup baik dalam penerimaan materi dapat membantu peserta lainnya.

\section{KESIMPULAN}

Berdasarkan hasil temuan dan pembahasan pada penelitian ini maka dapat disimpulkan bahwa pengelolaan pembelajaran pada diklat teknis substantif PKG dan PKB bagi guru Madrasah 'Aliyah di Balai Diklat Keagamaan Bandung Tahun 2018 telah berjalan efektif. Hal ini terbukti dengan perolehan skor secara rerata dari 
keseluruan indikator pengelolaan pembelajaran sebesar 88, 53 dengan predikat terpenuhi dengan sangat baik. Selain itu berdasar pada hasil wawancara dan catatan anekdot peneliti didapat kesimpulan secara umum bahwa diklat PKG dan PKB memberi dampak sangat positif bagi peserta diklat.

Efektivitas

pengelolaan pembelajaran pada diklat tersebut diperoleh dari persepsi melalui isian lembar instrument observasi dan wawancara serta catatan peneliti yang kemudian diperkuat dengan hasil pengisian lembar penilaian peserta diklat terhadap penyelenggaraan program diklat dalam bentuk lembar observasi yang telah disediakan oleh Balai Diklat Keagamaan Bandung. Adapun kendala yang dihadapi dalam pengelolaan pembelajaran diklat ini adalah pada indikator pengelolaan materi diklat yaitu sub indikator penggunaan metode pembelajaran yang bervariasi serta materi diklat yang menuntut cara berfikir analisis dan sintesis, serta indikator pengelolaan organisasi pembelajaran pada sub indikator langkah-langkah kegiatan pembelajaran dan transisi antar tahapan pembelajaran disampaikan dengan jelas dan disertai rangkuman. Kendala tersebut dapat teratasi dengan metode pembelajaran kolaboratif melalui pengelompokkan peserta diklat sehingga terjalin kerja sama yang baik dimana peserta diklat yang cukup baik dalam penerimaan materi dapat membantu peserta lainnya.

\section{DAFTAR PUSTAKA}

Baharun, H. (2018). Peningkatan kompetensi guru melalui sistem kepemimpinan kepala madrasah. At-Tajdid: Jurnal Ilmu Tarbiyah, 6(1), 1-26.

Fattah, Nanang. (2004). Landasan Manajemen Pendidikan. Bandung: Rosdakarya.

Gunawan, Rahmat Dwi. (2017). Studi Tentang Kompetensi Widyaiswara dalam Mengelola Pembelajaran di Lembaga Penjaminan Mutu Pendidikan Daerah Istimewa Yogyakarta. E-Jurnal Prodi Teknologi Pendidikan Vol. VI Nomor 5 Tahun 2017.

Hidayat, A. I., \& Sa'ud, U. S. (2015). Model Pendidikan dan Pelatihan Berbasis Kompetensi bagi Widyaiswara Muda. Jurnal Administrasi Pendidikan, 22(2).

Meitaningrum, Dhita Ayu, Imam Hardjanto dan Siswidiyanto. (2000). Efektivitas Pendidikan dan Pelatihan dalam meningkatkan Kinerja Pegawai (Studi pada Badan Kepegawaian Daerah Kabupaten malang), Jurnal Administrasi Publik (JAP), Vol. 1, No. 3. Jurusan Administrasi Publik, Fakultas Ilmu Administrasi, Universitas Brawijaya, Malang.

Rezeki, Sri., Murniati AR., dan Cut Zahri Harun. (2015). Manajemen Pembelajaran Pendidikan dan Pelatihan Prajabatan Pada BKPP Aceh. Jurnal Administrasi Pendidikan Pascasarjana Universitas Syiah Kuala. 
Sedarmayanti. (2009). Manajemen Sumber Daya Manusia: Reformasi Birokrasi dan Manajemen Pegawai Negeri Sipil. Yogyakarta: Aditama.

Sumantri, Rita Fahdila. (2012). Kompetensi Pengelolaan Pembelajaran, Kecerdasan Interpersonal, Komitmen dan Kepuasan Kerja Guru SMK. Jurnal Ilmu Pendidikan, Jilid 18, Nomor 1, Juni 2012. Universitas Negeri Malang. Pada situs http://journal.um.ac.id/index.php/ji p/article/ view/3380 (diunduh pada 11 Mei 2018)

Susetyowati, N. (2019). Pengaruh kompetensi pengelolaan pembelajaran terhadap kinerja Widyaiswara melalui pendidikan dan pelatihan sebagai mediasi (Doctoral dissertation, UNNES)

Yaqin, Husnul. (2011). Administrasi dan Manajemen Pendidikan. Banjarmasin: IAIN Antasari press Banjarmasin. 